\title{
Urgensi kerjasama personil bimbingan konseling di sekolah
}

\author{
Azmatul Khairiah Sari ${ }^{*}$ ), Neviyarni $\mathrm{S}^{2}$, Riska Ahmad ${ }^{3}$, \& Yarmis Syukur ${ }^{4}$ \\ STIT Ahlusunnah Bukittinggi ${ }^{1}$, Universitas Negeri Padang ${ }^{234}$ \\ *) Alamat korespondensi: JI. Ahmad Yani No. 83, Bukit Tinggi, 26136, Indonesia; E-mail: \\ azmatulkhairiah998@gmail.com
}

Article History: Received: 20/03/2021; Revised: 21/06/2021; Accepted: 21/06/2021; Published: $30 / 06 / 2021$.

How to cite: Sari, A.K., S, Neviyarni, Ahmad, R., \& Syukur, Y. (2021). Urgensi kerjasama personil bimbingan konseling di sekolah. Teraputik: Jurnal Bimbingan dan Konseling, 5(1), pp. 30-39. DOI: 10.26539/teraputik.51603

\begin{abstract}
Abstrak: Bimbingan dan konseling merupakan hal yang harus ada di sekolah. Kehadiran bimbingan dan konseling di sekolah diharapkan dapat membantu siswa mencapai kemandirian dan mengembangkan potensinya. Kemampuan siswa dalam mencapai kemandirian dan mengembangkan potensi diri menunjukkan bahwa bimbingan berhasil pada siswa tersebut. Tujuan penelitian adalah menguraikan urgensi kerjasama personil bimbingan dan konseling di sekolah. Metode penelitian ini adalah studi literatur. Keberhasilan bimbingan dan konseling di sekolah tentunya tidak terlepas dari kerjasama tenaga bimbingan konseling di sekolah. Tenaga bimbingan konseling harus bekerja sama dalam menciptakan keberhasilan konseling. Keberhasilan konseling juga merupakan prestasi bagi sebuah sekolah. Siswa di sekolah tersebut akan mengembangkan potensinya dengan sebaik-baiknya.
\end{abstract}

Kata Kunci: Kerjasama, Personel Bimbingan Konseling

Abstract: Guidance and counseling is a must in schools. The presence of guidance and counseling in schools is expected to help students achieve independence and develop their potential. The ability of students to achieve independence and develop self-potential shows that the guidance is successful for these students. The purpose of the study was to describe the urgency of the cooperation of guidance and counseling personnel in schools. This research method is literature study. The success of guidance and counseling in schools certainly cannot be separated from the cooperation of counseling guidance staff in schools. Counseling guidance personnel must work together in creating successful counseling. The success of counseling is also an achievement for a school. Students in these schools will develop their potential as well as possible.

Keywords: Cooperation, Counseling Guidance Personnel access article under the Creativ

Commons 4.0 Attribution

License, which permits

unrestricted use, distribution,

and reproduction in any medium, provided the original work is properly cited. (C) 2021, Sari, A.K., S, Neviyarni, Ahmad, R., \& Syukur, Y. (s).

\section{Pendahuluan}

Pendidikan adalah usaha sadar dan terencana yang diberikan oleh pendidik kepada peserta didik. Tujuan dari adanya pendidikan adalah adanya perubahan tingkah laku dan pemahaman yang lebih baik mengenai kehidupan. Pendidikan bisa dijalankan secara informal, formal dan non formal. Pendidikan formal dilaksanakan di sebuah sekolah. Sekolah yang dimulai dari tingkat SD, SMP sederajat dan SMA sederajat dan bahkan juga Perguruan Tinggi. Peserta didik akan menjalani tingkatan pendidikan secara formal dan akan mendapatkan pendidikan sesuai dengan jenjang pendidikan formal tersebut.

Dalam proses pendidikan secara forrmal, akan didapati tiga hal yang harus dijalani selama proses pendidikan tersebut, yaitu, administrasi, pengajaran dan bidang pengembangan pribadi siswa (Sukatma, 2012). Dalam bidang pendidikan harus memiliki bukti sebagai bukti secara administrasi. Pengajaran berarti proses belajar mengajar di dalam kelas yang biasanya kita dapati dalam pendidikan formal. Dan yang terakhir dalam pendidikan formal harus ada pengembangan kepribadian siswa yang biasanya dilakukan oleh guru bimbingan konseling. Dan lebih kita kenal dengan bimbingan konseling.

Guru bimbingan konseling/konselor sekolah mempunyai tanggung jawab sebagai tenaga kependidikan yang memberikan andil dalam proses pendidikan di sekolah sesuai dengan 
bidangnya yaitu memberikan pelayanan bimbingan dan konseling kepada peserta didik (Hayati, 2017). Selain itu guru bimbingan konseling merupakan guru yang bertugas memberikan bantuan psikologis dan kemanusiaan secara ilmiah dan professional sehingga seorang guru bimbingan konseling harus berusaha menciptakan komunikasi yang baik dengan murid dalam menghadapi masalah dan tantangan hidup (Sukardi, 2008:6).

Guru bimbingan konseling sebagai tombak pelaksana bimbingan konseling akan bekerja secara profesional dan dengan baik bagaimana seluruh siswa yang menjadi sasaran layannnya dapat mengembangkan potensi dirinya dan merasakan seperti apa konseling tersebut. Dengan adanya pengembangan potensi diri yang optimal dari masing-masing siswa maka siswa akan menjalankan kehidupan efektif sehari-hari yang menjadi tujuan dalam bimbingan konseling.

Guru bimbingan konseling harus memenuhi keterampilan yang menyangkut pendidikan akademik, kepribadian, keterampilan berkomunikasi dengan orang lain dan penggunaan teknikteknik konseling sebagai syarat untuk menjadi guru bimbingan konseling profesional (Winkel, 1991: 495). Guru bimbingan konseling harus memiliki kualifikasi akademik yang memang tamatan dari jurusan bimbingan konseling, memiliki kepribadian yang baik dan disenangi orang sekitar, memiliki kemampuan dalam menjalin komunikasi dengan orang lain sehingga konseling yang dijalankan berjalan dengan baik dan bisa menjalin komunikasi dengan personil bimbingan konseling lainnya. Selain itu diharapkan guru bimbingan konseling menguasai teknik-teknik dalam konseling baik itu teknik umum maupun teknik khusus. Guru bimbingan konseling juga bisa memanfaatkan keterampilannya ini untuk diterapkan pada personil bimbingan konseling sekolah.

Pelaksanaan bimbingan konseling di sekolah merupakan suatu proses yang integral antara seorang guru bimbingan konseling dengan personil bimbingan konseling lainnya. Pelaksana utama dalam bimbingan konseling memang guru bimbingan konseling namun tentu guru bimbingan konseling harus mendapat dukungan dari personil bimbingan konseling lainnya.

Dalam sebuah sekolah tentu personil bimbingan konseling lainnya harus mengetahui bahwa seorang guru bimbingan konseling harus menampakkan eksistensinya dan juga bisa berperan besar dalam pelaksanaan konseling. Personil bimbingan konseling lainnya harus membantu mengikis anggapan yang menyatakan bahwa guru bimbingan konseling tidak memiliki pekerjaan jelas di sebuah sekolah dan anggapan yang miring tentang guru bimbingan konseling tersebut (Nurhayati, dkk, 2018). Personil bimbingan konseling lainnya harus ikut serta dalam mensosialisasikan bimbingan konseling dan bisa mendapatkan image positif dari siswa dan masyarakat luas secara umumnya. Hal ini perlu dilakukan karena adanya kesalahfahaman yang cukup tersebar luas di tengah-tengah siswa dan masyarakat mengenai bimbingan konseling di sekolah.

Banyaknya kesalahfahaman mengenai bimbingan konseling dalam dunia pendidikan hendaknya dicegah penyebarannya, kemudian harus diluruskan agar pelayanan bimbingan dan konseling berjalan dan berkembang dengan baik sesuai dengan teori keilmuan dan praktik penyelenggaraannya dalam bimbingan konseling tersebut (Derliani, 2018). Perlu adanya kerjasama dari personil bimbingan konseling di sekolah untuk meminimalisir kesalahfahaman tentang bimbingan konseling di sekolah tersebut (Sari, dkk, 2021). Maka personil bimbingan konseling di sekolah memang mengetahui dengan baik apa yang harus ia lakukan dalam menjalankan keberhasilan konseling di sekolah tersebut dan menggugurkan anggapan tidak baik mengenai bimbingan konseling di sekolah.

Terlaksananya program bimbingan konseling dengan baik di sebuah instansi pendidikan formal atau sekolah akan mendatangkan manfaat yang besar. Adapun manfaat yang didapatkan adalah memungkinkan guru bimbingan konseling untuk meminimalkan waktu/biaya dengan menghindari kesalahan-kesalahan yang bisa saja terjadi. Dengan berhasilnya program konseling di sekolah maka siswa-siswa akan mendapatkan pelayanan secara seimbang dan menyeluruh, baik dalam hal kesempatan maupun jenis pelayanan yang diperlukan. Pelaksanaan bimbingan konseling di sekolah yang berhasil maka akan meudahkan guru Bimbingan konseling dalam memberikan pelayanan bimbingan konseling kepada siswa secara berimbang dan menyeluruh. Guru bimbingan konseling tidak hanya berfokus pada seorang siswa saja dan guru bimbingan konseling bisa menyentuh seluruh siswa tanpa ada yang dibeda-bedakan. 
Pekerjaan guru bimbingan konseling yang dibilang cukup banyak dan komplek ini membutuhkan bantuan dari personil bimbingan konseling lainnya agar keberhasilan konseling yang memang diharapkan oleh semua pihak bisa dicapai. Keberhasilan konseling yang menjadi idaman masing-masing guru bimbingan konseling akan dicapai dengan mudah apabila guru bimbingan konseling mendapat dukungan dan support dari personil bimbingan konseling lainnya yang juga memahami tugas dan kewajibannya masing-masing.

Namun yang kita dapati di instansi pendidikan formal kebanyakan adalah beberapa masalah-masalah yang kurang bersinergi dengan program bimbingan konseling yang sudah dirumuskan oleh guru bimbingan konseling. Seperti kurangnya kesadaran dan pemahaman pihak personil bimbingan konseling lainnya ketika program bimbingan konseling siap untuk dijalankan. Atau bisa juga ketika program bimbingan konseling dijalankan pada siswa namun personil bimbingan konseling sekolah lainnya mencemooh pelaksanaan program bimbingan konseling tersebut dihadapan siswa. Masalah lainnya yang bisa merusak keberhasilan konseling di sekolah. Maka dibutuhkan kerjasama dari masing-masing personil bimbingan konseling lainnya.

\section{Metode}

Metode yang digunakan dalam penulisan artikel ini adalah penelitian kualitatif. Desain yang digunakan adalah studi literatur yang mengumpulkan dari beberapa sumber-sumber referensi untuk menguraikan urgensi kerjasama personel bimbingan dan konseling di sekolah. Keterbatasan metode ini adalah tidak langsung terjun ke lapangan dalam melakukan penelitian. Hasil yang dituangkan adalah berdasarkan lapangan yang telah dituangkan dalam berbagai sumber yang ditelaah dan dibahas secara ringkas dan tuntas.

\section{Hasil dan Diskusi}

\section{Personil bimbingan konseling sekolah}

Personil pelaksana pelayanan bimbingan adalah segenap unsur yang terkait di dalam organigram pelayanan bimbingan, dengan koordinatir dan guru bimbingan konseling sebagai pelaksana utamanya (Sukardi, 2000: 55). Masing-masing personel bimbingan konseling di sekolah memiliki tugas, tanggung jawab dan hal apa saja yang harus ia laksanakan selama menjalankan program bimbingan konseling. Personel bimbingan konseling di sekolah akan terlihat dari adanya organisasi Bimbingan konseling.

Dalam organisasi akan terlihat kemana arah koordinasi kerja bimbingan konseling dan bagaimana pendelagasian tugas dalam menunjang keberhasilan konseling di sekolah. Personil bimbingan konseling di sekolah mengupayakan terjadinya keberhasilan konseling di instansi pendidikan formal yang menaunginya. Adapun personil bimbingan konseling di sekolah terdiri dari:

1. Personal pada Kantor Dinas pendidikan yang bertugas melakukan pengawasan atau penyediaan dan pembinaan terhadap penyelenggaraan bimbingan konseling di satuan pendidikan. Untuk Dinas pendidikan sendiri memiliki kewenangan dan hak dalam mengatur seperti apa pelaksanaan dari bimbingan konseling di daerah yang ia pimpin. Berbeda dinas pendidikan bisa jadi akan berbeda pula dalam membuat sebuah kebijakan mengenai bimbingan konseling di sekolah-sekolah yang ia pimpin tersebut. Dinas pendidikan adalah bagian yang merupakan bagian dari pemerintah daerah yang mengurus mengenai pendidikan.

2. Kepala sekolah. Kepala sekolah terdiri dari dua suku kata yaitu kepala dan sekolah. Kepala diartikan ketua atau pemimpin dalam sebuah organisasi dan sekolah adalah lembaga tempat dimana menuntut ilmu dan menerima ilmu (Wahyusimdjo, 2002: 83). Kepala sekolah berarti ketua dalam sebuah organisasi di sekolah yang akan memimpin jalannya sebuah sekolah dan akan bertanggung jawab secara penuh dengan apa yang dilakukan oleh anggota organisasinya termasuk program bimbingan konseling oleh guru bimbingan konseling. 
3. Wakil kepala sekolah. Wakil kepala sekolah bertugas membantu kepala sekolah dalam menjalankan tugasnya. Wakil kepala sekolah pada setiap sekolah berbeda-beda. Ada yang berjumlah tiga orang, ada yang dua orang atau ada yang satu orang saja. Tergantung pada kebutuhan sebuah sekolah. Wakil kepala sekolah bidang kesiswaan, wakil kepala sekolah bidang kurikulum dan wakil kepala sekolah bidang sarana prasarana, wakil kepala sekolah bidang hubungan masyarakat dan sebagainya. Namun apabila dikaitkan dengan organisasi bimbingan konseling di sekolah, semua wakil kepala sekolah akan berkaitan dengan pelaksanaan bimbingan konseling di sekolah tersebut.

4. Koordinator bimbingan konseling. Apabila koordinasi yang dilakukan berjalan dengan baik maka pelaksanaan bimbingan konseling akan efektif dan efesien. Dengan efektif dan efisien ini maka pelaksanaan bimbingan konseling akan dengan mudah mendekati keberhasilan suatu konseling. Setiap personil sekolah dan unit kerja diminta untuk menjalankan tugas dan kewajiban masing-masing guna menunjang terjadinya pelaksanaan program bimbingan konseling di sekolah tersebut. (Sukardi, 2002: 130). Koordinasi yang baik adalah apabila terjadinya komunikasi yang baik antara personil bimbingan konseling di sebuah sekolah. Koordinator bimbingan konseling sebagai penggerak dari terjadinya pelaksanaan bimbingan konseling di sekolah.

5. Guru Bimbingan Konseling. Guru bimbingan konseling merupakan profesi yang sudah diakui keberadaannya di sekolah. Hal ini dapat dilihat pada Peraturan Pemerintah Republik Indonesia Nomor: 74 tahun 2008 tentang Guru pada pasal 15 yang mengatakan, bahwa guru Bimbingan dan Konseling atau konselor adalah guru pemegang sertifikat pendidikan (Komalasari,dkk, 2011: 5). Oleh sebab itu, kehadiran guru bimbingan konseling ditengah personil bimbingan konseling lainnya memang membawa pencerahan pada pengembangan sikap dari siswa di sekolah tersebut. Guru bimbingan konseling harus bisa memberikan peran yang besar dalam mencapai keberhasilan konseling di sekolah.

6. Guru mata pelajaran. Guru Mata pelajaran wajib menjalankan perannya dengan baik dalam pelaksanaan bimbingan konseling (Sutirna, 2019). Dan pelaksanaan bimbingan konseling bagi guru mata pelajaran tentu tidak sekomplek yang dilakukan oleh guru bimbingan konseling. Guru mata pelajaran melaksanakan bimbingan konseling disaat jam pembelajaran berlangsung dan itu sudah terintegrasi antara bimbingan konseling dan penyampaian bahan materi pembelajarannya.

7. Wali Kelas. Wali kelas memiliki peran yang juga besar dalam keberhasilan konseling. Wali kelas hendaknya bekerjasama dengan guru mata pelajaran dan guru bimbingan konseling dalam mensukseskan konseling bagi siswa (Atmaja, dkk, 2019). Wali kelas adalah guru yang paling memahami siswa-siswanya. Karena wali kelas dianggap sebagai orangtua kedua bagi siswa di sekolah. Wali kelas harus memahami siapa saja siswanya dan apa yang bisa ia lakukan untuk mendekati siswanya. Maka wali kelas juga harus bisa emmberikan sebuah bimbingan konseling ketika diajaka berbicara oleh siswanya tersebut. Dan tentu saja ini harus terintegrasi dengan guru bimbingan konseling karena wali kelas harus mengetahui siswa dan seluk beluk siswanya.

Dalam pengelolaan pelayanan konseling di sekolah harus didukung dengan adanya organisasi, personil pelaksana, sarana prasarana dan pengawasan pelayanan bimbingan konseling. Pada masing-masing personil bimbingan konseling di sekolah memiliki tugas, wewenang dan tanggung jawab masing-masing yang terhubung langsung dengan organisasi pelayanan bimbingan konseling (Salahuddin, 2010: 172). Guru bimbingan konseling sebagai pemegang inti pelaksanaan bimbingan konseling di sekolah, wali kelas yang memang memahami bagaimana siswa yang ada di kelasnya masing-masing. Dan koordinator bimbingan konseling memegang andil untuk mengontrol jalannya bimbingan konseling di sekolah. Sementara koordinator bimbingan konseling akan melaporkan seluruh kegiatan bimbingan konseling kepada wakil kepala sekolah dan kepala sekolah. Sementara kepala sekolah berwenang dalam membuat kebijakan dalam pelaksanaan bimbingan konseling di sekolahnya. Dan tentu sudah dapat persetujuan sebelumnya dari dinas pendidikan di daerah tempat sekolah tersebut berdiri.

Bentuk struktur organisasi personil bimbingan konseling pada masing-masing satuan pendidikan berbeda-beda. Tergantung pada kebutuhan di sebuah sekolah dan juga ketersediaan 
sumber daya manusia yang ada. Tugas dan wewenang serta tanggung jawab pada masingmasing personil bimbingan konseling di sekolah disesuaikan dengan kondisi sekolah dan tidak mengurangi tuntutan akan efektivitas dan efesiensi bimbingan konseling di sekolah. Karena sasaran utama dari bimbingan konseling di sekolah adalah siswa maka personil bimbingan konseling harus bekerjasama untuk keberhasilan konseling bagi siswa yang ada di sekolah tersebut. Berikut struktur organisasi personil bimbingan konseling di sekolah secara umum.

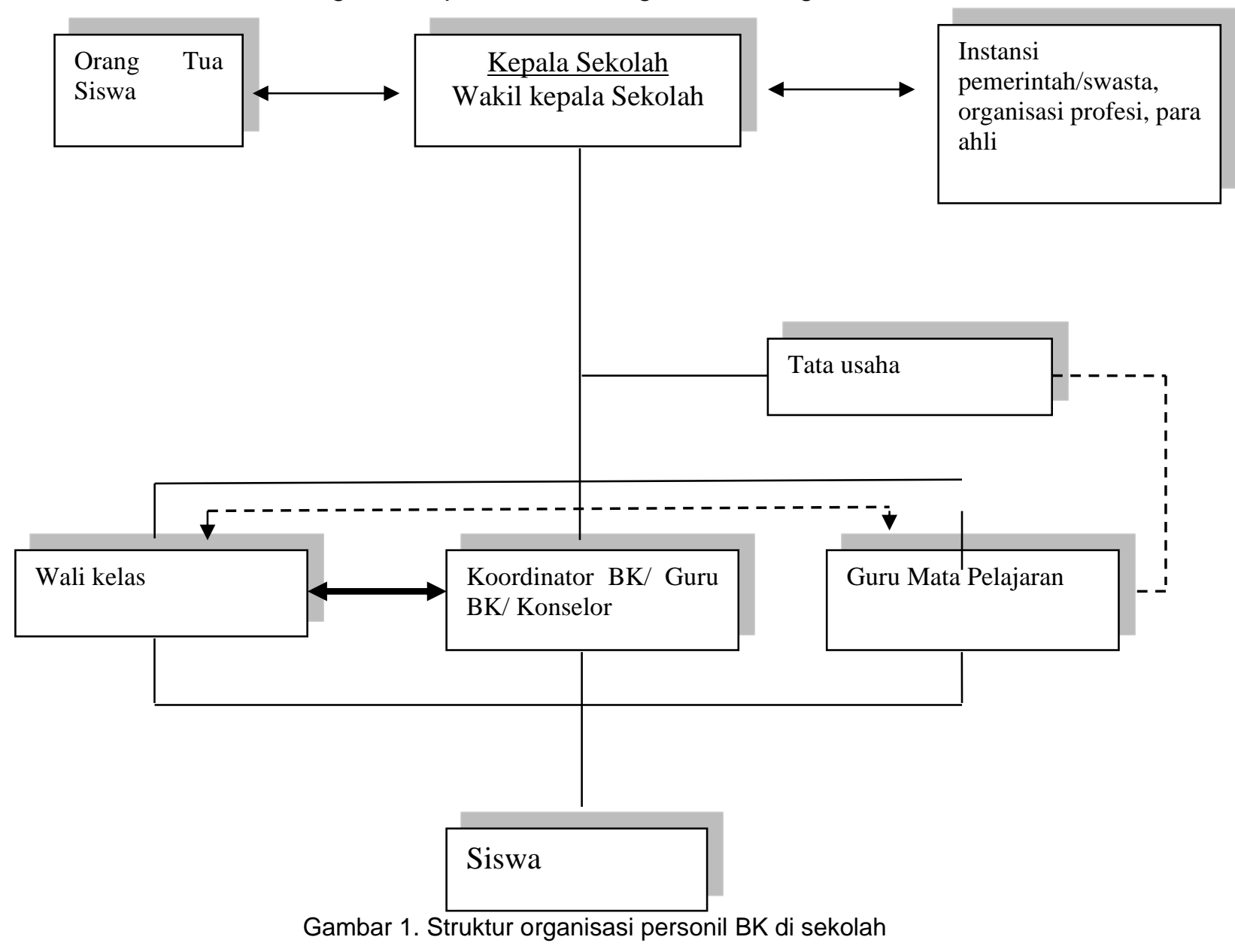

Keterangan :

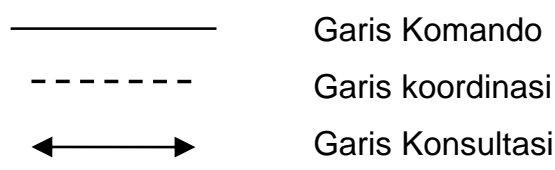

Dari struktur organisasi di atas dapat diambil kesimpulan bahwa, kepala sekolah bertanggung jawab penuh atas pelaksanan layanan bimbingan konseling disebuah sekolah. Kepala sekolah dan orang tua serta pihak yang bisa dimintai pendapat (bukan berasal dari sekolah) akan diajak bermusyawarah mengenai suatu permasalahn atau bagaimana pelaksanaan layanan bimbingan konseling di sebuah sekolah. Selanjutnya didelegasikan kepada koordinator bimbingan konseling/guru bimbingan konseling.

Kemudian dari guru bimbingan konseling akan berkoordinasi dengan guru mata pelajaran dan wali kelas dan pada akhirnya layanan bimbingan konseling diberikan kepada siswa yang ada di sekolah tersebut. Siswa yang ada di sekolah sebagai objek sasaran utama dari layanan bimbingan konseling. Dan pastinya ada prinsip-prinsip pemberian layanan yang harus dijaga oleh personil bimbingan konseling di sekolah. Prinsip bimbingan konseling adalah aturan main dalam pelaksanaan program yang harus diikuti (Kurniati, 2018). Selanjutnya pelayanan bimbingan konseling yang sesuai dengan prinsip maka pelaksanaan bimbingan konseling sebagai upaya 
memfasilitasi siswa dalam mengembangkan potensi diri dan atau mencapai tugas perkembangannya (Kamaluddin, 2011). Personil bimbingan konseling di sekolah hendaknya bekerja sama dalam memfasilitasi siswa dalam mengembangkan potensi dan mencapai tugas perkembangan sesuai dengan fase perkembangannya.

Personil bimbingan konseling yang berada di sebuah manajemen bimbingan konseling harus dilaksanakan dengan baik. Dari manajemen bimbingan konseling untuk personil bimbingan konseling harus memiliki pembagian tugas dan harus mengadakan sosialisasi secara rutin dan perlu diagendakan dengan terstruktur. Guru bimbingan konseling harus menyampaikan kinerja kerja dan program bimbingan konseling ke semua pihak. Adapun dari Dinas Pendidikan perlu kerja keras dalam sosialisasi undang-undang bimbingan dan konseling ke guru bimbingan konseling atau konselor yang ada di sekolah melalui ABKIN. Sehingga guru bimbingan konseling/konselor sekolah memahami dan tahu hak dan kewajiban secara ideal, serta harus profesional dalam pelaksanaan bimbingan konseling tersebut. Guru bimbingan konseling atau konselor di sekolah hendaknya menjaga bagaimana interaksi atau komunikasi dengan personil bimbingan konseling lainnya dalam segala situasi dan kondisi (Rahman, dkk, 2017).

\section{Kerjasama personil bimbingan konseling di sekolah}

Kerjasama antar personil bimbingan konseling di sekolah perlu dilakukan untuk membantu siswa dalam mencapai tugas perkembangan. Masing-masing personil bimbingan konseling di sekolah hendaknya memahami sekali apa yang harus ia lakukan dalam mendukung terlaksananya bimbingan konseling di sekolah. Dan dengan begitu siswa akan bisa mengaktualisasikan dirinya apabila ia bisa mengembangkan potensi dan menguasai tugas perkembangan dengan baik.

Adapun personil bimbingan konseling di sekolah juga harus memahami tugas apa saja yang ia lakukan untuk berkontribusi dalam pelayanan bimbingan konseling di sekolah. Berikut rincian tugas pada masing-masing personil bimbingan konseling disekolah (Sukardi, 2000, 55):

1. Kepala sekolah. Dalam sebuah sekolah, kepala sekolah berperan sebagai manajer di sebuah sekolah. Kepala sekolah bertanggung jawab atas pelaksanaan pendidikan secara komprehensif di sekolah yang ia pimpin tersebut. Sebagai seorang manajer, kepala sekolah memiliki tugas sebagai berikut.

a. Mengkoordinasikan segenap kegiatan yang diprogramkan di sekolah, sehingga layanan bimbingan konseling dan pembelajaran di kelas menjadi satu padu dan harmonis. Antara program bimbingan konseling yang disusun dengan pembelajaran di kelas yang dilakukan oleh guru mata pelajaran harus ada harmonisasi dan kesesuaian tujuan. Apabila ada kesenjangan maka akan membuat bimbingan konseling menjadi negatif di mata siswa.

b. Menyediakan sarana dan prasarana yang menunjang terlaksananya program bimbingan konseling yang efektif dan efisien. Sarana prasarana yang memadai akan mendukung terlaksananya bimbingan konseling. Kita misalkan saja untuk pelaksanaan layanan konseling individu butuh adanya sarana prasana agar kegiatan konseling perorangan menyenangkan dan membuat klien bersemangat mengadakan konseling.

c. Melakukan pengawasan terhadap program bimbingan konseling yang sudah disusun oleh guru bimbingan konseling/konselor/koordinator bimbingan konseling mulai dari perencanaan, pelaksanaan, evaluasi dan tindak lajut. Karena program bimbingan konseling dimulai dari adanya perencanaan, maka kepala sekolah harus mengetahui apa yang akan dilaksanakan oleh guru bimbingan konseling di sekolahnya. Proses pelaksanaanya juga harus diketahui oleh kepala sekolah. Pada akhirnya kepala sekolah bisa menilai kemajuan atau kegagalan dari pelaksanaan program bimbingan konseling yang sudah direncanakan oleh guru bimbingan konseling.

d. Mempertanggung jawabkan pelaksanaan pelayanan bimbingan konseling kepada atasannya seperti Kanwil/Kandep yang berwenang. Kepala sekolah akan melaporkan pelaksanaan bimbingan konseling di sekolahnya kepada pihak Kanwil/Kandep atau Dinas Pendidikan. Apabila ada suatu permasalahan pada 
pelaksanaan bimbingan konseling, maka pihak Kanwil/Kandep/Dinas Pendidikan akan menegur kepala sekolah untuk melakukan pembenahan terhadap sekolah tersebut.

2. Wakil Kepala Sekolah. Wakil kepala sekolah membantu kepala sekolah dalam tugastugas kepala sekolah dan termasuk di dalamnya pelaksanaan bimbingan konseling. Dalam pelaksanaan bimbingan konseling, wakil kepala sekolah yang membidangi bagian tertentu akan memberikan kontribusi. Sebagai contoh wakil kepala sekolah bidang kurikulum akan menetapkan dalam jadwal tersebut jam masuk untuk guru bimbingan konseling.

3. Koordinator Bimbingan konseling. Koordinator bimbingan bertugas mengkoordinasi para guru bimbingan konseling dalam hal:

a. Memasyarakatkan pelaksanaan bimbingan konseling kepada seluruh warga sekolah, orangtua siswa dan masyarakat. Hal ini dilakukan agar banyak pihakpihak yang tidak lagi mempertanyakan bimbingan konseling dan menganggap bimbingan konseling dengan sebelah mata. Seperti yang sudah dijelaskan sebelumnya, bahwa banyaknya kesalahfahaman yang tersebarluas mengenai bimbingan konseling.

b. Menyusun program bimbingan. Program bimbingan adalah apa saja yang akan dilakukan dalam pemberian layanan bimbingan konseling. Dalam konsep manajemen bisa kita katakan sebagai sebuah perencanaan dari pihak koordinator bimbingan konseling dalam pelaksanaan bimbingan konseling.

c. Melaksanakan program bimbingan. Koordinator bimbingan konseling akan mengkoordinir guru bimbingan konseling/Konselor untuk melaksanakan program yang sudah direncanakan. Dengan dilaksanakannya program maka dalam konsep manajemen dinamakan actuating/pelaksanaan.

d. Mengadministrasikan pelayanan bimbingan. Koordinator bimbingan konseling mengadministrasikan bagaimana bimbingan konseling diberikan kepada siswa. Dan tidak terlepas dari adanya laporan-gur laporan kegiatan yang akan dan telah dilaksanakan kemudian ada bukti secara otentik.

e. Menilai program bimbingan konseling. Setelah program diberikan, tentu ada tahapan dimana menilai apakah program yang dilaksanakan sudah tepat atau ada hal yang kurang. Dalam penilaian juga melihat sejauh mana program bimbingan konseling yang direncanakan sudah sesuai dengan keadaan siswa di lapangan.

f. Menindak lanjuti program bimbingan konseling. Setelah adanya penilaian maka akan didapatkan hasil. Hasil mengenai pelaksanaan bimbingan konseling. Apabila pelaksanaan bimbingan konseling berhasil maka sudah ada rumusan mengenai tindak lanjut keberhasilan bimbingan konseling tersebut. Apabila tidak berhasil, maka juga harus jelas apa yang akan dilakukan sebagai tindak lanjut dari penilaian evaluasi tersebut.

4. Guru Bimbingan Konseling. Adapun mekanisme kerja yang harus dilakukan oleh personil bimbingan konseling di sekolah adalah sebagai berikut.

a. Memasyarakatkan pelayanan bimbingan konseling. Guru bimbingan konseling sebagai pelaksana utama bimbingan konseling juga bertanggung jawab dalam memasyarakatkan bimbingan konseling di lingkungan sekitarnya. Termasuk kepada siswanya juga harus disosialisasikan bagaimana pelaksanaan bimbingan konseling. Semakin rutin seorang guru bimbingan konseling memanfaatkan bimbingan konseling maka akan semakin banyak pula yang mengetahui tentang program kerja bimbingan konseling.

b. Merencanakan program bimbingan konseling. Perencanaan program bimbingan konseling dalam rangka mempersiapkan layanan apa saja yang akan diberikan kepada siswa selama jangka waktu tertentu.

c. Melaksanakan program bimbingan konseling. Apa yang sudah menjadi perencanaan guru bimbingan konseling harus diaplikasikan kepada siswa yang menjadi target layanan bimbingan konseling di sekolah. 
d. Melaksanakan kegiatan pendukung bimbingan konseling. Disamping adanya layanan bimbingan konseling, kegiatan pendukung bimbingan konseling dilaksanakan sebagai pelengkap dari layanan bimbingan konseling.

e. Menilai proses dari pelayanan konseling yang telah dilaksanakan kepada siswa. Dari penilaian akan bisa diketahui apakah bimbingan konseling berjalan baik atau tidak. Yang dinilai adalah layanan konseling dan kegiatan pendukung bimbingan konseling yang telah diberikan pada siswa.

f. Melaksanakan tindak lajut dari penilaian yang telah diberikan kepada siswa di sekolah. Tindak lajut akan bisa dilakukan apabila telah dimulai terlebih dahulu dengan penilaian.

g. Mengadministrasikan layanan bimbingan konseling dan kegiatan pendukung yang telah dilaksanakan kepada siswa. Layanan bimbingan konseling dan kegiatan pendukung bimbingan konseling perlu bukti pelaksanaannya sebagai kelengkapan administrasi di sekolah.

h. Guru bimbingan konseling mempertanggungjawabkan bimbingan konseling apa yang dilakukan dalam pelayanan bimbingan konseling kepada koordinator bimbingan konseling. koordinator bimbingan konseling di sekolah menerima laporan pelaksanaan bimbingan konseling dari guru bimbingan konseling yang kemudian disikapi oleh koordinator bimbingan konseling.

5. Guru Mata pelajaran. Guru mata pelajaran adalah guru yang membidangi mata pelajaran tertentu. Sehari-hari guru mata pelajaran mengahdapi siswa dan juga mengerti bagaimana siswa yang ia hadapi. Adapun tugas dari guru mata pelajaran, antara lain:

a. Memasyarakatkan bimbingan konseling. Hal ini dalam rangka membantu guru bimbingan konseling dalam memudahkan tugasnya mensosialisasikan bagaimana bimbingan konseling tersebut.

b. Membantu untuk megidentifikasi mana siswa yang memerlukan bantuan dalam bentuk pelayanan konseling.

c. Mengalihtangankan siswa yang perlu bantuan pelayanan bimbingan konseling kepada guru bimbingan konseling. dalam rangka guru bimbingan konseling dan guru mata pelajaran saling bekerjasama dalam memberikan bantuan.

d. Menerima siswa yang dialihtangankan oleh guru bimbingan konseling, dan dianggap untuk remedial dan pengayaan tentang materi pelajaran. pada siswa yang diberikan bantuan tentang materi pelajaran diserahkan kepada guru mata pelajaran yang memang ahli di bidang tersebut.

e. Membantu mengembangkan suasana kelas yang kondusif agar hubungan antara siswa dan guru bisa lebih interaktif dan hubungan yang terjalin lebih baik lagi.

f. Memberikan jalan dan kemudahan pada siswa yang akan mengikuti pelaksanaan layanan bimbingan dan konseling. Dengan adanya kemudahan dari guru bimbingan konseling untuk siswa maka siswa akan menganggap bahwa bimbingan konseling memang menjadi perhatian utama di sekolah tersebut.

g. Ikut berpartisipasi dalam kegiatan khusus dalam memecahkan masalah siswa seperti konferensi kasus. Karena guru mata pelajaran bisa memberikan masukan kepada guru bimbingan konseling mengenai siswa tersebut.

h. Membantu menilai program bimbingan konseling. Penilaian bimbingan konseling perlu untuk mengetahui seperti apa tindak lanjutnya. Apabila tindak lanjut memerlukan guru mata pelajaran maka guru mata pelajaran juga harus memberikan kontribusi.

6. Wali Kelas. Wali kelas sebagai pengelola kelas tertentu, dan wali kelas berperan penting dalam pelaksanaan bimbingan konseling. Adapun peran wali kelas, antara lain:

a. Membantu guru bimbingan konseling untuk menjalankan tugas khusus yang dipercayakan padanya di kelas. Tugas untuk bimbingan konseling pada wali kelas menjadi tanggung jawabnya.

b. Membantu guru bimbingan konseling untuk menjalankan peranannya dalam bimbingan konseling. 
c. Mempermudah siswa untuk mengikuti bimbingan konseling. Karena wali kelas harus bekerjasama dengan guru bimbingan konseling untuk mengembangkan potensi dan mencapai tugas perkembangannya.

Bentuk kerjasama yang bisa dilakukan adalah guru mata pelajaran dan wali kelas memberikan data mengenai siswanya. Data yang akan diberikan berupa daftar nilai siswa, hasil observasi mengenai siswa, catatan anekdot, dan data lainnya yang diperlukan untuk bimbingan konseling. Setelah data didapatkan maka data diberikan kepada guru bimbingan konseling. Pada guru bimbingan konseling mencoba merumuskan program layanan yang bisa diberikan kepada siswa tersebut.

Pada guru bimbingan konseling menyusun data-data siswa untuk diarsipkan dan dibukukan dengan rapi. Data tersebut disimpan dalam ruangan. Setelah itu guru bimbingan konseling melaksanakan layanan kepada siswa dan tetap memberikan bukti layanan tersebut kepada bagian usaha yang nantinya untuk diarsipkan.

Sementara pada siswa yang bermasalah, guru bimbingan konseling bisa langsung memberikan layanan konseling atau mendapat ssiwa yang bermasalah dari guru mata pelajaran atau dari wali kelas. Koordinasi ini sangat diperlukan agar bimbingan konseling bisa berjalan dengan baik.

Perlunya kerjasama antara personil bimbingan konseling di sekolah dalam rangka mewujudkan program layanan bimbingan konseling agar berhasil. Dengan berhasilnya layanan bimbingan konseling akan menyebabkan siswa merasa bahagia dalam menjalani kegiatan pembelajaran. Dan siswa yang memang membutuhkan arahan dan bimbingan bisa memahami bahwa dirinya adalah individu dengan berbagai potensi baik untuk dikembangkan.

\section{Simpulan}

Perlunya kerjasama antara personil bimbingan konseling untuk mewujudkan konseling yang berhasil. Dengan profesional yang dimiliki masing-masing personil bimbingan konseling di sekolah akan mengarah kepada individu yang memahami potensi baik dan positif dalam dirinya. Akan timbullah suatu kebanggan dan kepuasan tersendiri bagi personil bimbingan konseling ketika siswa dapat meraih kebahagiaan dan mengembangkan potensi baik dan positif dalam dirinya.

Personil bimbingan konseling hendaknya mendukung program bimbingan konseling dengan menjalankan tugas dan kewajiban masing-masing. Dan apabila diperlukan personil bimbingan konseling memberikan fasilitas dan juga waktu dalam pelaksanaan bimbingan konseling di sekolah. Seperti kepala sekolah memberikan peluang kepada guru bimbingan konseling untuk masuk kedalam kelas melakukan pendekatan dengan siswa asuhnya. Wali kelas bagian kurikulum memberikan jam khusus untuk guru bimbingan konseling. Serta guru mata pelajaran dan wali kelas memberikan saran dan masukan kepada siswa untuk selalu ke ruangan bimbingan konseling dan dekat dengan guru bimbingan konseling.

\section{Ucapan Terima Kasih}

Ucapan banyak terima kasih kepada Suami yang sudah meberikan motivasi dan perhatian kepada penulis sehingga penulis dapat menyelesaikan tulisan ini. Selanjutnya anakanak penulis yang waktu bermainnya tidak ditemani oleh penulis karena penulis banyak fokus pada tulisan ini. Selanjutnya rasa terima kasih kepada keluarga yang mendukung penulis. Selanjutnya dosen yang telah membimbing penulis selama pembuatan tulisan ini. 


\section{Daftar Rujukan}

Atmaja, Surya Dharma. Edi Harapan, \& Nurlela. Implementasi Peran Wali Kelas Dalam Pelaksanaan Bimbingan Dan Konseling Di SMK Negeri 1 Benakat. Juang, Jurnal Wahana Konseling, p-ISSN: 2622-9080 e-ISSN: 2622-6278, Vol 2, No 2 (2019).

Derliani, Nurfaridah. Konsepsi (Kesalahpahaman) Bimbingan Dan Konseling Dalam Pendidikan. al-Irsyad, Jurnal Bimbingan dan Konseling Islam., p 111-126.

Hayati, Fitri. Peran Guru Bimbingan Dan Konseling Dalam Mengatasi Kecenderungan Perilaku Agresif Peserta Didik Di MA, Jurnal Manajer Pendidikan, Volume 10, Nomor 6, November (2016) p. 603-607.

Kamaluddin, Bimbingan dan Konseling Sekolah. Jurnal Pendidikan dan Kebudayaan, Vol. 17, Nomor 4, Juli (2011).

Komalasari, Gantina. Eka Wahyuni \& Karsih. (2011). Teori dan Teknik Konseling. Jakarta: Indeks.

Kurniati, Erisa. Bimbingan Dan Konseling Di Sekolah; Prinsip Dan Asas. RISTEKDIK | Jurnal Bimbingan dan Konseling. Volume 3 Nomor 2, Halaman 1-77, Juli-Desember 2018. PISSN: 2527-4244, E-ISSN : 2541-206X

Nurhayati, Nanik \& Siti Nurfarida PW. Optimalisasi Peran Dan Fungsi Guru Bimbingan Dan Konseling Dalam Implementasi Kurikulum 13. Jurnal Bikotetik Volume 02 Nomor 02. (2018),147-154

Rahman, K.A., Muhamad Muspawi, Titin Martini. Manajemen Bimbingan Dan Konseling Di SMA Negeri. Jurnal Administrasi Pendidikan Vol.XXIV No.1 April 2017.

Sari, Azmatul Khairiah. Prayitno, Yeni Karneli. Pelayanan Profesional Guru Bimbingan konseling Dalam Meminimalisir Kesalahpahaman Tentang Bimbingan konseling Di Sekolah. Journal of Education and Teaching Learning (JETL) Volume 3, Issue 1, January 2021 Page 36-49.

Sukardi, Dewa Ketut. (2000). Pengantar Pelaksanaan Bimbingan dan Konseling di Sekolah. Jakarta: PT. Rineka Cipta

Sukardi, Dewa Ketut. (2002). Manajemen Bimbingan dan Konseling di Sekolah. Bandung; Alfabeta.

Sukatma, Peranan Personil Sekolah Dalam Pelaksanaan Bimbingan Dan Konseling Di SMKN 1 Manado. Jurnal Ta'dib, Volume 15, No. 1 (Juni 2012).

Sutirna, LAYANAN BIMBINGAN DAN KONSELING: BAGI GURU MATA PELAJARAN. Jurnal Bimbingan dan Konseling Ar-Rahman Volume 5, Nomor 1,Tahun 2019 Tersedia Online: http://ojs.uniska.ac.id/index.php/BIMBINGAN KONSELINGA e-ISSN 2477-6300.

Wahjosumidjo, (2002). Kepemimpinan Kepala Sekolah, Tinjauan Teoritik dan Permasalahannya. Jakarta: PT Raja Grafindo Persada

Winkel, W.S. (1991). Bimbingan Dan Konseling Di Institusi Pendidikan, Jakarta: PT. Grasindo

\section{Competing interests:}

The authors declare that they have no significant competing financial, professional or personal interests that might have influenced the performance or presentation of the work described in this manuscript. 